AL IBTIDA: JURNAL PENDIDIKAN GURU MI (2018) Vol 5 (2) : 205-220

DOI: http://dx.doi.org/ 10.24235/al.ibtida.snj.v5i2.2679

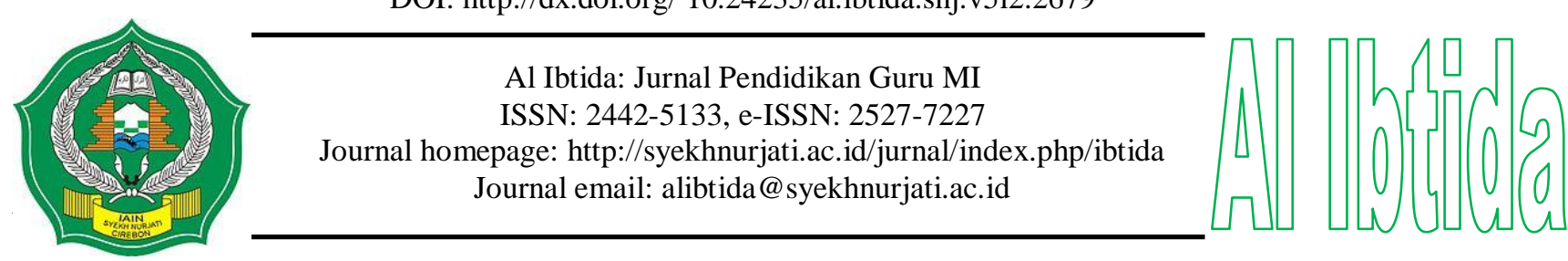

\title{
Sistem Karantina Tahfidzh 1 Hari untuk Anak Usia SD/MI di Rumah Tahfidzh Al-Haramain Kota Banjarmasin
}

\author{
Muhammad Iqbal Ansari* \\ *Program Studi Pendidikan Guru Madrasah Ibtidaiyah, Fakultas Studi Islam, \\ Universitas Islam Kalimantan Muhammad Arsyad Al-Banjari, Banjarmasin \\ Email: muhammadiqbalansari13@gmail.com \\ Barsihanor** \\ **Program Studi Pendidikan Guru Madrasah Ibtidaiyah, Fakultas Studi Islam, \\ Universitas Islam Kalimantan Muhammad Arsyad Al-Banjari, Banjarmasin \\ Email: barsihanor90@gmail.com
}

\begin{abstract}
Received 26 May 2018; Received in revised form: 15 October 2018; Accepted 16 October 2018
Publish Online: 30 October 2018
\end{abstract}

\begin{abstract}
Abstrak
Pada umumnya seorang santri di Indonesia merampungkan hafalan Al-Qur'an dalam jangka 2 - 4 tahun. Jangka waktu selama itu menjadi kendala bagi sebagian orang karena harus meninggalkan aktifitas demi fokus menghafal Al-Qur'an. Salah satu solusi dari permasalahan tersebut adalah Karantina Tahfidzh Al-Qur'an 1 Hari, sebuah kegiatan di mana peserta diasramakan untuk fokus menghafal Al-Qur'an selama 1 hari. Tujuan penelitian ini adalah mendeskripsikan pelaksanaan Karantina Tahfidzh Al-Qur'an 1 Hari untuk anak usia SD/MI di Rumah Tahfizh Al-Haramain, mendeskripsikan capaian hafalan dan kriteria peserta yang mencapai hafalan paling banyak, serta mengetahui kendala yang dihadapi. Penelitian ini menggunakan pendekatan kualitatif dengan jenis studi kasus. Data primer yang digunakan yaitu: narasumber, aktivitas, dan lokasi. Analisis dilakukan dengan proses pengumpulan, reduksi, paparan, verifikasi data, dilanjutkan dengan pengambilan simpulan. Validitas data dilakukan dengan triangulasi. Hasil penelitian menunjukkan bahwa 1) Karantina Tahfidzh Al-Qur'an 1 Hari untuk anak usia SD/MI di Rumah Tahfizh Al-Haramain dilaksanakan pada hari sabtu setelah shalat ashar hingga hari Ahad ketika dhuhur. Kegiatan ini dilaksanakan dengan dua program, yaitu inti dan pelengkap, 2) capaian hafalan peserta usia SD/MI paling tinggi adalah 62 baris atau 4 halaman, sedangkan paling rendah adalah 30 baris atau 2 halaman, 3) hafalan paling banyak dicapai oleh 3 peserta perempuan yang duduk di kelas V dan VI. Ketiga peserta tersebut merupakan santri yang cerdas secara akademik dan mempunyai bacaan Al-Qur'an yang sesuai tajwid, dan 4) kendala yang dihadapi dalam kegiatan ini ialah kondisi peserta yang kelelahan, sesi setoran pagi yang terlambat, kesalahan hafalan, dan kualitas hafalan yang belum kuat.
\end{abstract}

Kata Kunci: karantina tafidzh al-Qur'an, 1 hari, siswa, SD/MI 


\begin{abstract}
In general, a santri in Indonesia completes memorization of the Qur'an in a period of 2-4 years. This long period of time is being the obstacle for some people to memorize, because they have to cut their activities off to get focus in memorizing. One of the solutions from the problem above is One-Day Tahfizh Quarantine Program, an event which all the participants placed in one place or dormitory to stay focus in memorizing Qur'an in one day. This research aims to describe the implementation of One-Day Tahfizh Qur'an Quarantine Program for elementary school students in Banjarmasin, to describe their achievement in memorizing and the criteria, and to find out the obstacles faced by the organizer and the participants. This research uses qualitative approach with case study. Sources of the primer data chosen in the research are informants, activities, and location. The analysis conducted from the proccess of collection data, reduction data, explanation, verification, and interpretation conclusion phase. Checking the validity of the data conducted with triangulation. The findings of the research: 1) One-Day Tahfizh Quarantine Program for elementary school students in Rumah Tahfizh Al-Haramain Banjarmasin conducted on weekends, which is on Saturday after Ashr prayer and finishes on Sunday Dzuhur Prayer. The activity holds with primer and complement programs; 2) The highest achievement is 62 lines, or 4 pages 2 lines, and the lowest achievement is 30 lines or 2 pages; 3) The most memorization is 3 female participants who are 2 fifth graders and 1 sixth grader. The three participants are smart students, having good beauty and correct recitation based on the structure; 4) obstacles faced by the organizer are tiring condition of the participants, late morning session, error memorization, and the weak quality of the memorization.
\end{abstract}

Keywords: tahfizh Qur'an quarantine, one-day, students, elementary school

\title{
PENDAHULUAN
}

Menghafal Al-Qur'an atau yang dikenal dengan tahfidzh Qur'an mendapat perhatian besar di kalangan masyarakat Indonesia sejak diadakannya program Hafizh Indonesia di sebuah stasiun televisi nasional. Tahfizh semakin berkembang seiring munculnya lembaga-lembaga pendidikan yang menjadikan kegiatan menghafal Al-Qur'an sebagai program unggulan. Misalnya SDIT Ukhuwah atau SDIT Al-Firdaus sebagai sekolah tingkat dasar di Kota Banjarmasin yang sejak awal berdiri menjadikan kegiatan menghafal Al-Qur'an sebagai ciri khas lembaga. Bahkan di SDIT Al-Firdaus, sebagai sekolah yang baru 6 tahun berdiri, pada kelas VI terdapat siswa yang sudah hafal 10 juz.

Tahfidzh menurut bahasa Arab berasal dari kata al-Hifzh, yang jika diterjemahkan bermakna "pemeliharaan" atau "penghafalan", karena fungsi menghafal ialah memelihara AlQur'an dalam ingatan. Adapun seseorang yang menghafal Al-Qur'an disebut hafidzh atau hamilul Qur'an, seperti yang disebutkan oleh Imam Nawawi pada judul karangannya "At-Tibyân fii Âdabi Hamalat al-Qur'an", yang berarti Penjelasan Tentang Tata Krama Menghafal alQur'an (Qatthan, 2012). 
Para ulama menekankan betapa pentingnya menghafal Al-Qur'an dengan membuat kesepakatan bahwa hukum menghafal Al-Qur'an adalah fardhu kifayah. Prinsip dari fardhu kifayah ini dimaksudkan bahwa harus ada minimal satu orang yang hafal Al-Qur'an dari suatu masyarakat, jika tidak maka masyarakat tersebut dianggap berdosa. Suyuthi dalam al-Itqan mengatakan "Ketahuilah, sesungguhnya menghafal Al-Qur'an itu adalah fardhu kifayah bagi umat" (Suyuthi, 1999). Pembelajaran Al-Qur'an, baik itu membaca dan menghafal, menjadi salah satu strategi Syekh Muhammad Arsyad Al Banjari dalam berdakwah menanamkan ajaran Islam kepada masyarakat Banjar, karena melalui pembelajaran Al-Qur'an terjadi komunikasi aktif dan verbal antara pendidik dan siswa (Qomariyah, 2016). Hasil penelitian yang dilakukan oleh (As-Shanie', 2008) yang berjudul Atsar Hifzh al-Qur'an al-Karim 'ala al-Shihhah alNafsiyyah membuktikan bahwa ketika kadar hafalan al-Qur'an siswa meningkat maka akan meningkat pula kesehatan jiwanya.

Dalam dunia pendidikan, anak pada usia sekolah dasar berada pada masa-masa emas untuk menghafal. Hal ini dibuktikan bahwa para tokoh-tokoh Islam pada zaman dahulu seperti Imam Syafi'i dan Ibnu Sina sudah hafal Al-Qur'an pada usia sekolah dasar, yaitu antara 6-12 tahun. Menurut Ar-Rifa'i dalam (Ansori, 2016) menyatakan bahwa usia terbaik untuk menghafal Al-Qur'an adalah sejak usia 3 tahun. Karena ketika itu akalnya mulai berkembang, memorinya masih bersih murni, dan masih mudah menuruti apa yang diperintahkan. Seorang penghafal al Qur'an dianjurkan untuk konsisten menggunakan satu jenis mushaf Al-Qur'an saja yaitu standar Al-Madinah An-Nabawiyyah, yaitu 1 halaman memuat 15 baris. Hal ini dilakukan agar ingatan tidak berubah-rubah karena beberapa jenis mushaf memiliki perbedaan tata letak ayat, sehingga jika seseorang mengganti-ganti mushaf ketika menghafal, maka dia akan kesulitan dalam mengingat letak ayatnya (Keswara, 2017).

Adapun metode yang dianjurkan untuk menghafal Al-Qur'an terbagi kepada dua jenis. Pertama, pengajaran untuk siswa yang bisa membaca mushaf menggunakan metode fardi. Adapun langkah-langkah metode fardi menurut (Muntada, 2012) yaitu 1) guru menentukan batasan ayat yang akan dihafal, 2) guru meminta siswa membacakan ayat-ayat yang akan dihafal dihadapannya dan membenarkan jika ada yang salah, 3) siswa membaca dan menghafal sendiri ayat-ayat yang ditentukan dengan suara yang keras agar melibatkan indra penglihatan dan pendengaran sekaligus, 4) Jika sudah dihafal, siswa menyetorkan hafalan kepada guru. Dan jika masih banyak kesalahan atau terbata-bata dalam menghafal, maka siswa harus mengulang hafalannya lagi hingga lancar. Kedua, metode pengajaran bagi siswa yang tidak bisa membaca mushaf, baik karena masih kecil, belum belajar, atau orang non-arab, atau karena sebab lain, maka caranya yaitu siswa diajar dengan metode talaqqi (didik-tekan), yaitu di mana guru membacakan suatu maqra berulang-ulang, kemudian siswa mengulangi bacaan guru berulang- 
ulang hingga benar dan lancar. Metode pengajaran seperti ini juga yang diterapkan di Pesantren Al-Hikmah Bobos, di mana santri diperbaiki bacaan Al-Qur'annya terlebih dahulu dengan cara melihat mushaf atau bi an-nadzhar (Lutfy, 2013).

Perkembangan pembelajaran tahfizh Al-Qur'an pada dasawarsa terakhir semakin pesat. Hal ini berdasarkan penelitian Sofyan (2015) yang bertajuk The Development of Tahfiz Qur'an Movement in The Reform Era in Indonesia. Dalam penelitian tersebut dikemukakan bahwa salah satu indikator pesatnya perkembangan kegiatan menghafal Al-Qur'an di Indonesia ialah munculnya Rumah Tahfizh yang dicetuskan oleh Daarul Qur'an yang diinisiasi oleh Yusuf Mansur. Terdapat hingga 300 buah lembaga di Indonesia yang dinaungi oleh Rumah Tahfizh Daarul Qur'an. Sistem Rumah Tahfidzh ini hampir sama dengan lembaga pendidikan dayah Tahfizd Ulumul Qur'an yang ada di Banda Aceh. Kedua lembaga ini sama-sama memfokuskan siswa untuk menghafal al-Qur'an. Proses menghafal Al-Qur'an dimulai pada sore atau malam hari, setelah para siswa selesai mengikuti kegiatan sekolah formal (Barri, 2016). Berbeda dengan pondok pesantren, Rumah Tahfiz didirikan dengan konsep "jemput bola", hadir di tengah-tengah masyarakat muslim, sehingga mereka dapat dengan mudah untuk mengembangkan potensi anakanak mereka dalam menghafal Al-Qur'an. Dan konsep Rumah Tahfizh ini yang kemudian diadopsi oleh lembaga-lembaga pendidikan Al-Qur'an di Indonesia, diantaranya adalah Rumah Tahfizh Al-Haramain yang berlokasi di Kota Banjarmasin, Kalimantan Selatan.

Atabik (2014) menyebutkan dalam penelitiannya yang berjudul The Living Qur'an: Potret Budaya Tahfiz Al-Qur'an di Nusantara bahwa dibutuhkan waktu sekitar 2 hingga 4 tahun untuk menyelesaikan hafalan 30 juz di pondok pesantren. Rentang waktu yang tergolong lama untuk menghafal Al-Qur'an. Oleh sebab itu, muncul berbagai program untuk mempercepat hafalan Al-Qur'an siswa. Diantaranya seperti penelitian yang dilakukan oleh Suwito (2016) yang berjudul Sistem Menghafal cepat selama 40 hari untuk $30 \mathrm{Juz}$ di Ma'had Tahfidz Al-Qur'an di Dawuhan Purbalingga dan penelitian yang dilakukan oleh Ansari (2017) yang berjudul Pelaksanaan Karantina Tahfizh selama 30 Hari untuk Usia SD/MI di Kota Banjarmasin.

Namun pada perkembangannya, program menghafal selama 30 atau 40 hari ini dianggap masih sulit untuk diikuti karena peserta harus meluangkan waktu selama 1 bulan penuh dan biaya yang dianggarkan untuk mengikuti kegiatan ini relatif besar (Ansari, 2017). Oleh karena itu, penting kiranya mencari alternatif lain guna memberikan kesempatan dan kemudahan bagi orang-orang yang ingin menjadi penghafal Al-Qur'an. Salah satu dari alternatif tersebut adalah diadakannya program karantina 1 hari tahfidzh Al-Qur'an.

Rumah Tahfidzh Al-Haramain yang terletak di Kelurahan Pekapuran Kota Banjarmasin merupakan salah satu lembaga pendidikan al Qur'an di Kalimantan Selatan yang menerapkan 
karantina tahfidz 1 hari. Berdasarkan penjajakan awal, ditemukan bahwa siswa mampu mencapai hafalan hingga 7 halaman atau 105 baris Al-Qur'an standar Mushaf Utsmani dalam waktu 1 hari program ini dilaksanakan. Pada pelaksanaan pertama karantina tahfidzh Al-Qur'an ini, peserta yang mendaftar hanya 85 orang, namun pada pelaksanaan yang kali kedua meningkat melebihi 100 orang, yang berarti minat dan tanggapan siswa terhadap program ini meningkat. Fenomena tersebut menarik perhatian penulis untuk mengadakan penelitian dengan judul "Sistem Karantina Tahfidzh 1 Hari untuk Anak Usia SD/MI di Rumah Tahfidzh Al-Haramain”. Mengacu kepada latar belakang di atas, penelitian ini bertujuan untuk mendeskripsikan sistem, capaian hafalan siswa usia SD/MI, kriteria siswa yang mencapai hafalan paling banyak, dan kendala yang dihadapi dalam pelaksanaan Karantina Tahfidzh 1 Hari di Rumah Tahfidzh Al-Haramain.

\section{METODE PENELITIAN}

Penelitian ini berjudul "Sistem Karantina Tahfidzh 1 Hari untuk Anak Usia SD/MI di Rumah Tahfidzh Al-Haramain" di Kelurahan Pekapuran Raya, Banjarmasin, Kalimantan Selatan. Berdasarkan judul tersebut, maka penelitian ini bersifat kualitatif untuk mencari gambaran atau deskripsi mendalam mengenai pelaksanaan kegiatan karantina tahfidzh untuk anak usia SD/MI. Menurut Bogdan \& Biklen yang dikutip oleh Rahmat (2009) bahwa metode kualitatif salah satu prosesur penelitian yang menghasilkan data deskriptif berupa kata-kata tertulis atau lisan dari orang-orang dan perilaku yang dapat diamati dan diarahkan pada latar dan individu secara utuh. Tujuan penelitian kualitatif adalah mencari dan memperoleh informasi mendalam dibandingkan dengan luas atau banyaknya informasi.

Adapun jenis penelitian yang digunakan dalam penelitian ini adalah studi kasus (case study). Menurut Ghony \& Fauzan (2012), studi kasus (case study) merupakan penelitian tentang suatu "kesatuan sistem." Kesatuan ini dapat berupa program, kegiatan, peristiwa, atau sekelompok individu yang terkait oleh tempat, waktu, dan ikatan tertentu. Dilihat dari kasus yang diteliti, menurut Endraswara yang dikuti oleh Rahardjo (2017), studi kasus dapat dibagi menjadi dua jenis, yaitu studi kasus berupa penyimpangan dari kewajaran dan studi kasus ke arah perkembangan yang positif. Studi kasus pertama bersifat kuratif, dan disebut studi kasus retrospektif (retrospective case study), yang memungkinkan dilakukan tindak lanjut penyembuhan atau perbaikan dari suatu kasus (treatment). Tindak penyembuhan tidak mesti dilakukan oleh peneliti, tetapi bisa dilakukan oleh orang lain yang kompeten. Peneliti hanya memberikan masukan dari hasil penelitian. Sedangkan yang kedua disebut studi kasus prospektif (prospective case study). Jenis studi kasus ini digunakan untuk menemukan kecenderungan dan arah perkembangan suatu kasus. Tindak lanjutnya berupa Penelitian Tindakan (Action Research) 
yang dilakukan juga oleh pihak lain yang berkompeten (Rahardjo, 2017). Dan pada riset ini, peneliti menggunakan jenis yang kedua ini, yaitu studi kasus prospektif.

Menurut Lofland \& Lofland yang dikutip Moleong (2011), sumber data utama dalam penelitian kualitatif ialah kata-kata dan tindakan, selebihnya adalah data tambahan seperti dokumen dan lain-lain. Data yang dibutuhkan dalam penelitian ini dapat dikumpulkan atau diperoleh dari berbagai sumber data. Pengertian sumber data dalam penelitian ini adalah subjek dari mana data dapat diperoleh (Widoyoko, 2012). Sumber data berupa data primer dan data sekunder, sumber data primer yang dipilih dalam penelitian ini yaitu narasumber (informan), peristiwa atau aktivitas, tempat atau lokasi. Sumber data sekunder yang menjadi rujukan peneliti dalam hal ini adalah berbagai dokumen yang didapat dari pihak penyelenggara, dalam hal ini pengurus Rumah Tahfidzh Al-Haramain, baik berupa dokumen tertulis seperti peraturan seleksi, biodata peserta, jadwal kegiatan, laporan hafalan, serta dokumen yang berbentuk foto dan data lain-lainnya.

Adapun teknik pengumpulan data yang digunakan adalah dengan wawancara, observasi, dan dokumentasi. Metode wawancara dilakukan untuk mendapatkan data dari pihak penyelenggara, seperti Ketua, guru, dan pengurus lainnya, serta untuk mendapatkan data dari peserta yang berada pada usia SD/MI. Bentuk interview yang digunakan penulis dalam penelitian ini adalah interview bebas dan terpimpin. Menurut (Atmadja, 2013), penelitian kualitatif disebut juga participant-observation, oleh karena itu peneliti sendiri yang menjadi pelaksana utama dalam pengumpulan data dengan cara mengamati langsung objek yang diteliti. Somantri (2005) menggunakan istilah "observasi terlibat", karena dalam penelitian ini, seorang peneliti kualitatif langsung terlibat dalam setting sosial.

Adapun analisis data dalam penelitian kualitatif ini bersifat iteratif (berkelanjutan) dan dikembangkan sepanjang penelitian. Analisis dilakukan mulai tahapan pengumpulan data, reduksi data, paparan data, serta verifikasi dan pengambilan kesimpulan. Pengecekan keabsahan data dilakukan dengan triangulasi sumber, teknik, dan waktu.

\section{HASIL DAN PEMBAHASAN}

\section{A. Sistem Karantina Tahfidzh 1 Hari untuk Anak Usia SD/MI}

Menurut Atabik (2014) dalam penelitiannya yang berjudul The Living Qur'an: Potret Budaya Tahfiz Al-Qur'an di Nusantara mengungkapkan bahwa para santri membutuhkan waktu sekitar 2 hingga 4 tahun untuk menyelesaikan hafalan 30 juz di pondok pesantren. Artinya, seseorang jika ingin menghafal Al-Qur'an harus bersedia untuk mondok di pesantren tahifidzh selama itu dan usia minimal santri adalah usia SMP/MTs. Seiring berkembangnya minat masayarakat terhadap pendidikan untuk menghafal Al-Qur'an, 
muncul berbagai program untuk cepat dalam menghafal Al-Qur'an. Di antaranya seperti penelitian yang dilakukan oleh Suwito (2016) tentang Sistem Menghafal cepat selama 40 hari untuk $30 \mathrm{Juz}$ di Ma'had Tahfidz Al-Qur'an di Dawuhan Purbalingga. Dalam riset tersebut diungkapkan bahwa motivasi belajar dan pembersihan jiwa yang menjadi kunci peserta dalam menghafal. Motivasi memberikan efek semangat yang tinggi, sebagaimana hasil penelitian yang dilakukan oleh Fatin (2017) yang berjudul Hubungan Self Management dengan Kemampuan Menghafal Al-Qur'an Santri di Pondok Tahfidz Syifa'ul Qur'an Surakarta bahwa kemampuan menghafal santri menjadi semakin baik ketika mereka mendapatkan motivasi. Sedangkan pembersihan jiwa mengarahkan peserta untuk selalu fokus dalam menghafal sehingga terhindar dari pikiran kotor. Namun dalam penelitian Suwito (2016) tersebut disebutkan bahwa kriteria peserta yang bisa mengikuti program tersebut minimal sudah berusia 15 tahun atau sudah lulus sekolah menengah pertama dan memiliki hafalan minimal 1 juz.

Berdasarkan penelitian yang dilakukan Atabik dan Suwito dapat diketahui bahwa kriteria calon penghafal Al-Qur'an tidak ada yang berusia SD/MI, hanya menerima usia SMP/MTs ke atas, karena menurut Suwito (2016), pada tahapan usia tersebut seorang calon penghafal secara mental dan kemandirian sudah dianggap matang. Berbeda dengan penelitian yang dilakukan oleh Ansari (2017) yang berjudul Pelaksanaan Karantina Tahfizh selama 30 Hari untuk Usia SD/MI. disebutkan bahwa program tersebut memberikan kesempatan bagi umat muslim usia SD/MI yang berminat untuk mengikuti aktifitas menghafal Al-Qur'an tanpa harus masuk ke pondok pesantren, terutama bagi mereka yang masih sekolah, karena diselenggarakan pada saat libur panjang. Kegiatan ini dilaksanakan 2 kali dalam 1 tahun.

Namun pada perkembangannya, program menghafal selama 30 atau 40 hari ini dianggap masih sulit untuk diikuti karena peserta harus meluangkan waktu selama 1 bulan penuh, yang berarti peserta harus meninggalkan aktifitasnya selama kegiatan tersebut. Tidak jarang beberapa peserta yang berusia sekolah harus izin di sekolah masing-masing dikarenakan masih mengikuti kegiatan tersebut. Ditambah lagi biaya pendaftaran karantina selama 30 atau 40 hari relatif besar, karena dianggarkan untuk membiayai akomodasi setiap peserta selama kegiatan berlangsung seperti makan, laundry, dan lain-lain (Ansari, 2017).

Karantina tahfidzh 1 hari bisa menjadi salah satu alternatif dari yang bisa diikuti oleh calon penghafal untuk menambah dan mempercepat kuantitas hafalan mereka. Selain itu, dengan seharian berkumpul bersama guru dan teman-temannya dapat meningkatkan kecerdasan sosial peserta, karena terdapat waktu yang lama antara mereka untuk saling berinteraksi (Ansari, 2015). Dan Rumah Tahfidzh Al-Haramain merupakan lembaga 
pendidikan Al-Qur'an yang melaksanakan kegiatan ini di Kota Banjarmasin, Kalimantan Selatan.

Rumah Tahfidzh Al-Haramain terbentuk pada tanggal 26 Maret 2014 dengan jumlah santri 22 orang dan 3 orang tenaga pengajar. Proses pembelajaran dilaksanakan di rumah Ustadz Sufyan Baly, Ketua Yayasan Al-Haramain, karena belum memiliki gedung sekolah khusus untuk kegiatan pembelajaran. Berkat bantuan para donator, Rumah Tahfidzh AlHaramain mampu membangun gedung belajar sendiri sehingga pada tahun ajaran 2016 mampu menampung santri yang berjumlah 320 orang dengan 18 tenaga pengajar. Rumah Tahfidzh Al-Haramain didirikan berdasarkan Peraturan Daerah (Perda) Kalimantan Selatan nomor 3 tahun 2009 tentang wajib belajar Al-Qur'an di sekolah umum mulai tahun ajaran 2010-2011. Adapun tujuan dari lembaga ini yaitu 1) membentuk Generasi Qur'ani (Cinta Qur'an) yang berakhlak mulia, 2) Menciptakan kaderisasi huffazh (penghafal Al-Qur'an) yang memahami figh dengan benar, 3) memberdayakan potensi anak, dan 4) Memberdayakan profesionalisme guru Al-Qur'an.

Lembaga pendidikan di bidang Al-Qur'an ini memiliki 2 macam program. Pertama, Education Program. Program ini berisi kegiatan tahsin dan tahfizh. Program tahsin merupakan program pendidikan yang bertujuan untuk meningkatkan kemampuan siswa dalam membaca Al-Qur'an sesuai dengan ilmu tajwid. Metode yang digunakan ialah metode Ummi yang terdiri dari 6 jilid dilengkapi dengan buku gharib dan tajwid. Awalnya program ini hanya untuk usia SD/MI ke atas, namun seiring meningkatnya minat masyarakat, lembaga membentuk kelas pra-tahsin, yaitu kelas anak usia dini. Sedangkan program tahfizh merupakan program menghadal Al-Qur'an bagi siswa yang sudah mampu membaca AlQur'an dengan baik sesuai ilmu tajwid. Kedua, Exclusive Program. Program ini merupakan program tambahan yang diadakan untuk berbagai tujuan. Misalnya ditujukan untuk mempererat tali silaturrahim antara lembaga dengan pihak masyarakat, maka diadakan Forum Silaturrahim Orang Tua dan Guru Tahfidzh (FSOG). Diadakan pula rihlah atau darmawisata dan perlombaan sebagai sarana refreshing. Dan untuk meningkatkan kemampuan siswa, diadakan Karantina Tahfizh 1 Hari sebagai program akselerasi bagi siswa yang ingin memperbanyak kuantitas hafalan.

Karantina Tahfizh 1 Hari merupakan program yang didasari atas keinginan siswa yang ingin mempercepat capaian hafalannya. Menurut salah seorang pengelola, tidak ada paksaan atau kewajiban kepada santri untuk mengikuti program. Hal ini dikarenakan jika atas dasar paksaan atau kewajiban, dikhawatirkan peserta akan tertekan secara psikologis sehingga memberikan dampak negatif pada proses pembelajaran, seperti tidak perhatian atau 
muncul persepsi negatif terhadap kegiatan menghafal Al-Qur'an. Ada dua hal yang memotivasi siswa untuk mengikuti program ini, yaitu ekstrinsik dan intrinsik. Motivasi ekstrinsik ialah berupa keinginan mendapatkan reward dan keinginan untuk mendapatkan pengalaman menyenangkan berkumpul bersama teman-teman selama satu hari satu malam yang diisi dengan kegiatan menghafal dan kegiatan hiburan. Menurut Santrock (2015), perspektif behavioral menekankan arti penting dari motivasi ekstrinsik untuk meningkatkan prestasi siswa, sedangkan pendekatan kognitif dan humanistis lebih menekankan pada arti penting motivasi intrinsik dalam prestasi. Misalnya dalam kegiatan karantina ini ialah kesenangan siswa terhadap membaca dan menghafal Al-Qur'an dan keinginan untuk menjadi salah satu dari orang-orang yang menjaga Al-Qur'an di dalam dadanya.

Program karantina ini dilaksanakan selama 1 hari 1 malam pada akhir pekan, yaitu dimulai dari sabtu sore hingga minggu siang. Program ini diisi dengan kegiatan setoran hafalan, motivating, makan minum, ibadah, olahraga, dan game. Sebelum program karantina 1 hari dilaksanakan, pengelola Rumah Tahfizh Al-Haramain terlebih dahulu membentuk panitia pelaksana yang terdiri dari ketua, sekretaris, bendahara, seksi acara, seksi konsumsi, dan petugas penerima setoran hafalan (muhafidzh). Selanjutnya disebarkan pengumuman untuk penerimaan pendaftaran program karantina tersebut kepada siswa. Satu hari sebelum hari pelaksanaan, panitia membagi para pendaftar menjadi 2 klasifikasi, yaitu kelompok tahsin dan tahfidzh. Usia dibatasi dari kelas 4 SD/MI hingga menengah atas. Setelah itu masing-masing klasifikasi dibagi ke dalam beberapa kelompok, di mana satu kelompok terdiri dari 12 peserta, dan setiap kelompok telah ditentukan para muhafizh-nya. Hasil pembagian kelompok ditempel di papan pengumuman. Adapun biaya yang ditetapkan untuk mengikuti program ini sebesar Rp.50.000.

Kegiatan dimulai pada hari sabtu pukul 16.00 WITA. Para peserta berkumpul di gedung belajar Rumah Tahfidzh Al-Haramain dan melaksanakan shalat ashar berjamaah. Selesai shalat, panitia memberikan pengarahan dan motivasi kepada peserta untuk menjalani proses pembelajaran. Selanjutnya para peserta menempati kelompok masing-masing dan mempersiapakan hafalan yang akan disetorkan. Proses setoran dengan cara guru atau muhafidzh duduk di depan, sedangkan peserta duduk berbaris di depan guru untuk menunggu giliran menyetorkan hafalan. Peserta terbagi kepada 2 tingkatan, tahsin dan tahfizh. Bagi tingkatan tahsin, peserta menyetorkan dulu maqra/batasan ayat yang akan dihafalnya, dan muhafidzh akan memperbaiki atau men-talaqqi bacaan ayat yang akan dihafal tersebut, setelah itu peserta duduk ke belakang barisan untuk menunggu giliran menyetorkan hafalan yang dihafal selama menunggu gilirannya. 
Berdasarkan penelitian Qawi (2017), metode talaqqi ini efektif meningkatkan kemampuan menghafal siswa. Materi yang dihafal oleh kelompok tahsin adalah juz 30, karena dianggap sebagai juz yang paling familiar. Selain itu berdasarkan penelitian Hasyim (2017) bahwa juz 30 sangat dianjurkan untuk menjadi awal juz dari Al-Qur'an yang harus dihafal, karena juz 30 merupakan juz yang paling sulit untuk dihafal karena mengandung ayat-ayat yang pendek sehingga perlu pikiran yang lebih fokus untuk mengingat kelanjutan ayat berikutnya dengan benar. Selain itu juz 30 juga memiliki halaman yang lebih banyak dari juz yang lain. Juz 30 diibaratkan sebagai penghalang utama, sehingga ketika seseorang mampu untuk melewatinya, maka rintangan berikutnya, yaitu menghafal juz yang lain, akan dilalui dengan mudah.

Adapun untuk tingkatan tahfizh, peserta langsung menghafal maqra/batasan ayat yang dihafal secara mandiri dan disetorkan langsung ke muhafidzh, karena bacaan peserta yang berada pada tingkatan ini minimal sudah pada tingkatan baik, kalaupun terdapat kesalahan yang terjadi adalah kesalahan kecil, seperti kesalahan pada pengucapan sifat huruf atau kurang teliti dalam membaca atau melafalkan maqra. Sesi setoran hafalan dilaksanakan sebanyak 4 kali, yaitu setelah shalat ashar, setelah shalat isya, setelah shalat shubuh dan pada pagi hari pukul 09.00 WITA. Satu sesi setoran berdurasi 60 menit. Satu kali sesi, peserta menyetorkan hafalan antara 3-4 kali. Dalam satu kali setoran, kuantitas ayat yang dihafal peserta berbeda-beda tergantung kemampuan dan tingkat kesulitan maqra yang dihafal. Jika menghafal maqra yang mudah, maka setoran akan lebih banyak. Namun jika menghafal maqra yang sulit, maka setoran akan lebih sedikit.

Program karantina ini juga diisi dengan kegiatan motivating yang dilaksanakan setelah shalat magrib. Kegiatan motivating diisi oleh seorang motivator guna memberi semangat dan arahan dalam menghafal. Pada saat peneliti melaksanaan riset, motivator yang diundang adalah Ustadz Muhammad Rusli, Kepala Sekolah SDIT Al-Firdaus, pencetus sekolah berbasis multiple intelligence di Banjarmasin. Kegiatan motivating ini selaras dengan riset yang dilakukan oleh (Hidayat, 2017) mengenai pembelajaran tahfizh untuk anak bahwa motivasi tentang keutamaan menghafal Al-Qur'an membekas secara psikologis bagi seorang hafizh. Pengetahuan tentang keutamaan dengan apa yang dialami memberikan dampak pada motivasi dan regulasi diri hafizh untuk giat menghafal. Beberapa ahli menjelaskan, regulasi diri merupakan kemampuan mengatur dan menjalankan tingkah laku sebagai strategi seseorang mencapai tujuan atau prestasi. Chaerani \& Subandi (2010) menjadikan teori regulasi diri ini untuk meneliti para santri-santri yang menghafal Al-Qur'an di sebuah pesantren di Yogyakarta. Beberapa responden riset tersebut menyampaikan keyakinan 
terhadap janji Allah Swt. tentang keutamaan menghafal Al-Qur'an yang menjadi sebab regulasi diri. Saptadi (2012) mengkategorikan kegiatan motivating ini sebagai sebuah bimbingan belajar agar siswa mengenali jati diri, menyeimbangkan kecerdasan intelektual, emosi dan spiritual.

Pada malam hari, peserta mengikuti program setoran hingga pukul 22.00 WITA, setelah itu istirahat, namun sebagian peserta masih ada yang mengulang atau mempersiapkan hafalan. Pada pukul 23.00 WITA semua peserta diwajibkan sudah tenang dan tidur. Hal ini dikarenakan pada dini hari pukul 04.00 WITA akan dilanjutkan dengan kegiatan shalat tahajjud. Setelah itu para peserta secara individu mengulang hafalan ataupun mempersiapkan hafalan yang akan disetorkan berikutnya. Al-Ghautsani mengungkapkan bahwa waktu dini hari, yaitu antara waktu sahur dan setelah shubuh, merupakan saat yang tepat untuk menghafal Al-Qur'an, karena otak seseorang belum dipenuhi dengan pikiran tentang perkara yang dapat menggangun fokusnya (Hidayah, 2016).

Kegiatan karantina ini bukan berisi kegiatan membaca-menghafal Al-Qur'an saja, namun juga diisi dengan olahraga yang dilaksanakan setelah setoran $b a$ 'da shubuh. Para peserta puteri mengikuti senam pagi di dalam area gedung, sedangkan peserta putera olahraga di halaman gedung belajar. Menurut (Tegawati, Karini \& Agustin, 2007), melalui olahraga seseorang akan senantiasa dalam kondisi perasaan yang nyaman. Kondisi perasaan yang nyaman menjadikan individu dapat mengoptimalkan proses mental yang berfungsi dan berpengaruh pula pada kemampuan individu menghadapi setiap permasalahan yang dapat menimbulkan depresi. Hal ini menjadi penting karena dalam proses penurunan depresi, faktor-faktor individual pada masing-masing individu yang kerjanya dipengaruhi proses mental juga berperan. Oleh karena itu olahraga memberikan peranan pada perubahan keadaan depresi individu.

Setelah berolahraga, para peserta beristirahat, mandi, shalat dhuha, dan makan pagi kemudian dilanjutkan dengan mengikuti setoran hafalan sesi terakhir. Sebelum kegiatan berakhir, dilaksanakan pengarahan sekaligus motivating dari para panitia. Selain itu, diselingi juga permainan berupa tebak-tebakan menyambung ayat Al-Qur'an yang dibacakan oleh panitia. Selagi kegiatan motivating, panitia yang lain mengumpulkan laporan hasil capaian hafalan peserta, dan mendaftar para peserta yang capaian hafalannya paling banyak akan mendapatkan penghargaan ketika acara penutupan yang dilaksanakan menjelang shalat dhuhur. Adapun jadwal kegiatan Karantina Tahfidzh 1 Hari sebagaimana tabel 1. 
Tabel 1. Jadwal Kegiatan Karantina Tahfidzh

\begin{tabular}{ccl}
\hline No & \multicolumn{1}{c}{ Waktu } & \multicolumn{1}{c}{ Kegiatan } \\
\hline 1 & $16.00-16.30$ WITA & Shalat Ashar berjamaah \\
\hline 2 & $16.30-17.00$ WITA & Pengarahan dan Persiapan Setoran \\
\hline 3 & $17.00-18.00$ WITA & Setoran Hafalan 1 \\
\hline 4 & $18.00-19.00$ WITA & Mandi, Wudhu, dan shlat Magrib Berjamaah \\
\hline 5 & $19.00-20.30$ WITA & Motivating dan Shalat Isya \\
\hline 6 & $20.30-21.00$ WITA & Makan Malam \\
\hline 7 & $21.00-22.00$ WITA & Setoran Hafalan 2 \\
\hline 8 & $22.00-03.30$ WITA & Istirahat/Tidur (Diperkenankan untuk Mengaji) \\
\hline 9 & $03.30-04.30$ WITA & Shalat Tahajjud \\
\hline 10 & $04.30-06.00$ WITA & Persiapan Hafalan\&Shalat Shubuh Berjamaah \\
\hline 11 & $06.00-07.00$ WITA & Setoran Hafalan 3 \\
\hline 12 & $07.00-08.00$ WITA & Olahraga/Senam \\
\hline 13 & $08.00-09.00$ WITA & Istirahat, Mandi, dan Makan \\
\hline 14 & $09.00-10.00$ WITA & Setoran Hafalan 4 \\
\hline 15 & $10.00-11.00$ WITA & Motivating \\
\hline 16 & $11.00-12.30$ WITA & Penutupan dan Pemberian Penghargaan bagi Santri \\
\hline 17 & $12.30-13.00$ WITA & Shalat Dhuhur Berjamaah dan Pulang \\
\hline & &
\end{tabular}

\section{B. Capaian Hafalan Peserta Karantina Tahfidzh 1 Hari Usia SD/MI}

Sesi setoran hafalan dilaksanakan sebanyak 4 kali, yaitu setelah shalat ashar, setelah shalat isya, setelah shalat shubuh dan pada pagi pukul 09.00 WITA. Satu sesi setoran berdurasi 60 menit. Satu kali sesi, peserta menyetorkan hafalan antara 3-4 kali. Dalam satu kali setoran, jumlah peserta berbeda-beda tergantung kemampuan dan kadar kesulitan maqra yang dihafal. Jika menghafal maqra yang mudah, maka setoran akan lebih banyak. Namun jika menghafal maqra yang sulit, maka setoran akan lebih sedikit. Berikut adalah jumlah setoran peserta karantina tahfidzh 1 hari yang berusia SD/MI:

Tabel 2. Capaian Hafalan Peserta (dalam baris)

\begin{tabular}{|c|c|c|c|c|c|c|c|}
\hline \multirow[t]{2}{*}{ No } & \multirow{2}{*}{$\begin{array}{c}\text { CAPAIAN } \\
\text { HAFALAN } \\
\text { (dalam } \\
\text { baris) }\end{array}$} & \multicolumn{2}{|c|}{ JUMLAH } & \multirow[b]{2}{*}{ Total } & \multicolumn{3}{|c|}{ Kelas } \\
\hline & & $\begin{array}{l}\text { Laki- } \\
\text { laki }\end{array}$ & Perempuan & & IV & $\mathbf{V}$ & VI \\
\hline 1 & 62 baris & 1 & 2 & 3 & 0 & 2 & 1 \\
\hline 2 & 54 baris & 1 & 6 & 7 & 0 & 4 & 3 \\
\hline 3 & 49 baris & 2 & 2 & 4 & 1 & 2 & 1 \\
\hline 4 & 47 baris & 1 & 2 & 3 & 1 & 0 & 2 \\
\hline 5 & 46 baris & 1 & 2 & 3 & 1 & 1 & 1 \\
\hline 6 & 45 baris & 1 & 2 & 3 & 0 & 1 & 2 \\
\hline 7 & 40 baris & 4 & 1 & 5 & 1 & 2 & 2 \\
\hline 8 & 36 baris & 2 & 2 & 4 & 1 & 2 & 1 \\
\hline 9 & 32 baris & 2 & 2 & 4 & 1 & 2 & 1 \\
\hline 10 & 30 baris & 6 & 11 & 17 & 3 & 5 & 9 \\
\hline & Total & 21 & 32 & 53 & 9 & 21 & 23 \\
\hline
\end{tabular}


Memperhatikan dari tabel 2, ditemukan bahwa peserta usia SD/MI mampu menghafal paling tinggi sebanyak 62 baris, atau 4 halaman 2 baris, yang berarti peserta tersebut rata-rata menyetorkan hafalan 15 baris Al-Qur'an dalam sekali sesi setoran. Peserta yang mencapai hafalan sebanyak ini ialah peserta yang duduk di kelas V (2 orang) dan kelas VI (1 orang). Sedangkan paling sedikit peserta menghafal 30 baris atau 2 halaman. Capaian hafalan hingga 30 baris merupakan yang paling banyak dicapai, yaitu 17 orang, artinya dari 4 kali sesi setoran, rata-rata mereka menyetor hafalan sebanyak 7-8 baris dalam 1 kali sesi setoran AlQur'an.

Jika laporan hafalan peserta diklasifikasikan dalam bentuk halaman. Satu halaman terdiri dari 15 baris dengan menggunakan standar mushaf Al-Madinah An-Nabawiyyah. Adapun hasilnya sebagai berikut:

Tabel 3. Capaian Hafalan Peserta (dalam halaman)

\begin{tabular}{ccccc}
\hline No & $\begin{array}{c}\text { CAPAIAN HAFALAN } \\
\text { (dalam halaman) }\end{array}$ & \multicolumn{2}{c}{ JUMLAH } & \\
\cline { 3 - 4 } & Laki-laki & Perempuan & Total \\
\hline 1 & 4 halaman ( $>$ 53 baris) & 2 & 8 & 10 \\
\hline 2 & 31/2 halaman (46-52 baris) & 4 & 6 & 10 \\
\hline 3 & 3 halaman (38-45 baris) & 5 & 3 & 8 \\
\hline 4 & 21/2 halaan (31-37 baris) & 4 & 4 & 8 \\
\hline 5 & 2 halaman (23-30 baris) & 6 & 11 & 17 \\
\hline \multicolumn{2}{c}{ Total } & 21 & 32 & 53 \\
\hline
\end{tabular}

Berdasarkan tabel 3 capaian hafalan peserta, ditemukan bahwa capaian hafalan yang paling banyak dicapai oleh peserta usia SD/MI ialah 2 halaman (30 baris), yaitu sejumlah 17 orang, 6 laki-laki dan 11 perempuan, yang berarti 34\% atau sekitar sepertiga dari jumlah peserta yang berusia SD/MI.

\section{Kriteria Peserta dengan Capaian Hafalan Paling Banyak}

Dari hasil wawancara dengan salah seorang muhafidzh, 3 peserta tersebut merupakan santri yang cerdas secara akademik di sekolah, dan mempunyai bacaan Al-Qur'an yang baik, benar, dan lancar. Mereka dengan mudah mampu membaca dan melafazkan setiap ayat dengan baik dan benar, sehingga pada saat proses setoran, dalam waktu yang terbatas, dia mampu menyetorkan hafalan dengan baik tanpa banyak mendapat teguran dari muhafizh. Dan dengan ingatan yang kuat, dia mampu menghafal dalam jumlah yang banyak. Selain itu mereka juga tergolong santri yang penurut, tidak bercanda dan berbicara dengan temannnya ketika sesi setoran, sehingga lebih fokus untuk menghafal. 


\section{Kendala dalam Pelaksanaan Karantina Tahfidzh 1 Hari}

Pelaksanaan Karantina Tahfidzh 1 Hari ini mempunyai kendala tersendiri. Berdasarkan hasil wawancara peneliti terhadap 3 orang pengelola Rumah Tahfizh AlHaramain, susunan jadwal program karantina yang diikuti pasti membuat tenaga peserta terkuras. Oleh karenanya masih ditemui peserta yang mengantuk ketika sesi setoran. Untuk mengatasi hal tersebut panitia menyediakan air minum untuk sekedar mengusir rasa kantuk. Kendala lainnya adalah terlambatnya sesi setoran dimulai, salah satunya pada saat setoran pagi. Hal ini dikarenakan peserta setelah olahraga para peserta akan mandi. Proses mandi pagi ini yang menyita waktu karena terbatasnya sarana kamar mandi, sehingga harus bergiliran.

Kendala berikutnya adalah kesalahan hafalan yang dibaca serta hasil hafalan yang belum terlalu kuat. Oleh karenanya peserta setelah mengikuti program karantina, akan menyetorkan hafalannya kembali pada program belajar reguler kepada guru pembimbingnya masing-masing, karena tujuan dari program karantina adalah akselerasi hafalan, dan murojaah-nya dilaksanakan di kegiatan belajar harian.

\section{SIMPULAN}

Berdasarkan hasil penelitian yang telah diuraikan, maka dapat disimpulkan sebagai berikut:

1. Karantina Tahfidzh Al-Qur'an 1 Hari untuk anak usia SD/MI di Rumah Tahfizh AlHaramain Banjarmasin dilaksanakan pada akhir pekan, yaitu dimulai pada hari sabtu setelah shalat ashar dan berakhir ketika shalat dhuhur. Kegiatan ini dilaksanakan dengan penerapan beberapa program, yaitu program inti dan program pelengkap.

2. Hasil capaian hafalan anak usia SD/MI yang mengikuti Karantina Tahfidzh 1 Hari di Rumah Tahfidzh Al-Haramain ditemukan bahwa peserta usia SD/MI mampu menghafal paling tinggi sebanyak 62 baris, atau 4 halaman 2 baris, yang berarti peserta tersebut rata-rata menyetorkan hafalan 15 baris Al-Qur'an dalam sekali sesi setoran. Peserta yang mencapai hafalan sebanyak ini ialah peserta yang duduk di kelas V (2 orang) dan kelas VI (1 orang). Sedangkan paling sedikit peserta menghafal 30 baris atau 2 halaman. Capaian hafalan hingga 30 baris merupakan yang paling banyak dicapai oleh para peserta, yaitu 17 orang, artinya dari 4 kali sesi setoran, rata-rata mereka menyetor hafalan sebanyak 7-8 baris dalam 1 kali sesi setoran Al-Qur'an.

3. Capaian hafalan paling banyak adalah perempuan dengan capaian 62 baris atau 4 halaman Al-Qur'an yang dicapai oleh 3 orang. Ketiganya berada pada kelas tinggi, yaitu kelas V dan 
VI. Tiga peserta tersebut merupakan santri yang cerdas secara akademik di sekolah, dan mempunyai bacaan Al-Qur'an yang baik, benar, dan lancar. Mereka dengan mudah mampu membaca dan melafazkan setiap ayat dengan baik dan benar, sehingga pada saat proses setoran, dalam waktu yang terbatas, mereka mampu menyetorkan hafalan dengan baik tanpa banyak mendapat koreksi dari muhafizh. Dan dengan ingatan yang kuat, mereka mampu menghafal dalam jumlah yang banyak. Selain itu mereka juga tergolong santri yang displin.

4. Kendala yang dihadapi dalam penyelengaraan Karantina Tahfizh 1 hari ialah, 1) kondisi peserta yang kelelahan sehingga mengantuk, 2) terlambatnya sesi setoran pagi dimulai dikarenakan peserta bergiliran untuk mandi, dan 3) kesalahan hafalan yang dibaca serta hasil hafalan yang belum terlalu kuat. karena tujuan dari program karantina adalah akselerasi hafalan, dan mengulangnya dilaksanakan di kegiatan belajar harian.

\section{DAFTAR PUSTAKA}

Ansari, M. I. (2015). Strategi Sistem Full Day School dalam Membentuk Empati Siswa. Jurnal Muallimuna, 1(1), 70-78.

Ansari, M. I. (2017). Pelaksanaan Karantina Tahfidzh 30 Hari untuk Anak Usia SD/MI. Jurnal Muallimuna, 2(2), 1-18.

Ansori. (2016). Peran Pengajian antara Maghrib Isya (PAMI) dalam Mengatasi Buta Aksara AlQur'an di Desa Olak Kecataman Muara Bulian-Batang Hari Jambi. Jurnal At-Tasyrih, 1(2), 184-197.

As-Shanie', S. I. (2008). Atsar Hifzh al-Qur'an al-Karim 'ala al-Shihhah al-Nafsiyyah. Jurnal Al-Imam Al-Syathibi Li Al-Dirasat Al-Qur'aniyyah.

Atabik, A. (2014). The Living Qur' an : Potret Budaya Tahfiz al-Qur'an di Nusantara. Jurnal Penelitian, 8(1), 161-177.

Atmadja, A. T. (2013). Pergulatan Metodologi dan Penelitian Kualitatif dalam Ranah Ilmu Akuntansi. Jurnal Akuntansi Profesi, 3(2), 122-141.

Barri, F. (2016). Manajemen Waktu Santri di Dayah Tahfidz Ulumul Qur'an Pagar Air Banda Aceh. Jurnal Ilmiah Didaktika, 17(1), 138-265.

Chairani, L., \& Subandi. (2010). Psikologi Anak Penghafal Quran, Peranan Regulasi Diri. Yogyakarta: Pustaka pelajar.

Fatin, H. (2017). Hubungan Self Management dengan Kemampuan Menghafal Al-Qur'an Santri di Pondok Tahfizdz Syifa 'ul Qur'an. Skripsi FITK IAIN Surakarta.

Ghony, M. J., \& Almanshur, F. (2012). Metodologi Penelitian Kualitatif. Jogjakarta: Ar-Ruzz Media.

Hasyim, A. W. (2017). Strategi Pembelajaran Al-Quran pada Lembaga Majelis Al- Qurra' Wa Al-Huffaz Pondok Pesantren As'adiyah Sengkang Kabupaten Wajo. Jurnal UIN Alauddin Makassar, 6(2), 355-366. 
Hidayah, N. (2016). Strategi Pembelajaran Tahfidz Al-Qur'an di Lembaga Pendidikan. Jurnal Ta'allum, 4(1), 64-81.

Hidayat, F. (2017). Kajian Psikologi Pembelajaran Hafal Quran bagi Anak Usia Dini. Proceedings of The 2nd Annual Conference on Islamic Early Childhood Education (C) 2017 Study Program of Islamic Education for Early Childhood, Faculty of Tarbiyah and Teaching Science, State Islamic University Sunan Kalijaga, Yogyakarta.

Keswara, I. (2017). Pengelolaan Pembelajaran Tahfidzul Qur'an (Menghafal Al Qur'an) di Pondok Pesantren Al Husain Magelang. Jurnal Hanata Widya, 6(2), 62-73.

Lutfy, A. (2013). Metode Tahfidz Al-Qur'an (Studi Komparatif Metode Tahfidz Al-Qur'an di Pondok Pesantren Madrasah al-Hufadzh II Gedongan Ender, Pangenan Cirebon dengan Pondok Pesantren Tahfidz Qur'an Terpadu Al- Hikmah Bobos, Dukupuntang Cirebon). Jurnal Holistik, 14(2), 157-173.

Moleong, L. J. (2011). Metodologi Penelitian Kualitatif. Bandung: Rosdakarya.

Qatthan, M. (2012). Pengantar Studi Ilmu Al-Qur'an. Jakarta: Kautsar.

Qawi, A. (2017). Peningkatan Prestasi Belajar Hafalan Al-Qur'an Melalui Metode Talaqqi di MTsN Gampong Teungoh Aceh Utara. Jurnal Ilmiah Islam Futura, 16(2), 265-283.

Qomariyah, N. (2016). Nilai-nilai Pendidikan Agama Islam dalam Pemikiran Syekh Muhammad Arsyad Al-Banjari Serta Relevansinya Terhadap Pendidikan Agama Islam di Indonesia. Tesis. UIN Sunan Kalijaga, Yogyakarta.

Rahardjo, M. (2017). Studi Kasus dalam Penelitian Kualitatif: Konsep dan Prosedurnya. Malang: Pascasarjana UIN Maulana Malik Ibrahim.

Rahmat, P. S. (2009). Penelitian Kualitatif. Jurnal Equilibrium, 5(9), 1-8.

Santrock, J. W. (2015). Psikologi Pendidikan. Jakarta: Kencana.

Saptadi, H. (2012). Faktor-faktor Pendukung Menghafal Al-Qur'an dan Implikasinya dalam Bimbingan Konseling. Jurnal Bimbingan Konseling, 1(2), 117-121.

Sofyan, M. (2015). The Development of Tahfiz Qur'an Movement in The Reform Era in Indonesia. International Journal of Religious Literature and Heritage, 4(1),115-136.

Somantri, G. R. (2005). Memahami Metode Kualitatif. Jurnal Makara Seri Sosial Humaniora, 9(2), 57-65.

Suwito. (2016). Sistem Menghafal cepat selama 40 hari untuk 30 Juz (Studi di Ma'had Tahfidz al-Quran di Dawuhan Purbalingga). Laporan Penelitian LP2M IAIN Purwokerto.

Suyuthi, J. (1999). Al-Itqan Fii Ulumil Qur'an. Beirut: Darul Fikri.

Tegawati, L. M., Karini, S. M., \& Agustin, R.W. (2007). Pengaruh Senam Lansia Terhadap Penurunan Tingkat Depresi Pada Orang Lanjut Usia. Surakarta: Prodi Psikologi FK UNS.

Tim Yayasan Muntada Islami. (2012). Panduan Mengelola Sekolah Tahfizh. Surakarta: AlQowam.

Widoyoko, E. P. (2012). Teknik Penyusunan Intrumen Penelitian. Yogyakarta: Pustaka Pelajar. 